\title{
Hip-preserving surgical treatment for atraumatic femoral head necrosis
}

\author{
A.E. Murzich, O.A. Sokolovsky, G.A. Uryev \\ State Institution Republican Scientific-Practical Centre of Traumatology and Orthopedics, Minsk, Belarus
}

\begin{abstract}
Introduction Hip-salvage treatment in femoral head necrosis has a great social and economic importance.The number of hip joint replacements in young patients has been increasing. Purpose To evaluate the results of hip-preserving surgical interventions in the treatment of patients with non-traumatic femoral head necrosis. Materials and methods The study included 42 cases treated by minimally invasive core decompression of the femoral head and bone grafting, 22 cases of decompression and introduction of autologous bone marrow and mesenchymal stem cells into the core of necrosis, and six cases of using a titanium locking mesh implant. Results The follow-up time after surgery was up to 5 years. The survival rate of hip-reserving operations using cell technology to stimulate osteoregeneration were noticeably better than using bone grafting only in disease stages I, IIA, IIB, IIC. For femoral head osteonecrosis in stage IIIA, a titanium locking femoral head implant has been developed. It promotes regeneration and performs a supporting function. Conclusion The analysis of long-term results of these minimally invasive technologies has proven their efficacy and safety along with a low rate of complications.
\end{abstract}

Keywords: femoral head necrosis, mesenchymal stem cells, joint replacement

\section{INTRODUCTION}

Osteonecrosis of the femoral head (OFH) is a severe hip pathology that is characterized by progressive disease course resulting in failure of femoral head support, its destruction and secondary coxarthrosis [1]. Bilateral involvement is observed in 50 to $75 \%$ of the disease cases and leads to disability and severe disorders in the lower limb function $[2,3]$.

As long as the disease mostly affects young population of working age and the number of total hip arthroplasties (THA) in patients with femoral head osteonectosis makes $7 \%$ to $14.8 \%$ of such interventions [4], the issues of its early diagnosis and treatment are of great social and economic importance.

In the Belarus Rebublic, the epidemilogical situation in regard to osteonecrosis is quite unclear due to imperfection of the centralized system for registering joint replacements and orthopaedic diseases. However, more than 6,000 THAs have been reported annually. Thus, the numer of osteonecrotic cases might be around 900 cases.

Decompression has been widely popular among the known techniques of osteonecrosis management. It implies reduction of the intramedullary pressure to promote inflow of cells from the areas surrounding the necrotic head lesion [5,6]. The opinions of orthopaedic surgens about the complexity of decompression techniques and outcomes are ambigous. The techniques differ in surgical approaches to the joint, number of drilled canals and diameters of holes.
A number of authors point to high efficiency of percutaneous multiple drilling with wires of small diameter, others prefer one wide canal $[7,8]$.

Another disputable isssue is the choice among the options for necrotic cavity filling. This stage of intervention should provide solutions to several tasks such as to strengthen the femoral head, be biocompatible and participate in regeneration. Currently, varios options of bone plasty have been proposed. They are autologous bone grafting or filling the cavity with bioresorbable materials, bone cement, composite calcium phospate and sulphate [9-11]. Additional vascularised bone and muscle grafts [12, 13], platelet-enriched autologous plasma [14] have been proposed for stimulation of regeneration, and allografts with plasma that is enriched with platelet growth factors [15].

However, the introduction of the technoques with proven efficiency into clinical practice is limited by the lack of technical supplies to hospitals, staff experience or substances for bone substitution. The technical performance has not been fully described in the literature to reproduce them and have not been proven by objective instrumental data. The factors mentioned above motivate the specialists to develop new surgical methods and techniques to substitute the nectotic bone tissue.

Purpose To evaluate the results of hip-preserving surgical interventions in the treatment of patients with femoral head osteonecrosis of atraumatic genesis. 


\section{MATERIAL AND METHODS}

Between 2014 and 2019, sisty-six patients (70 joints) with atraumatic OFH underwent surgcal treatment at the clinic of our institution for traumatology and orthopaedics. Group A of 42 patients unserwent minimally invasive core decompression of the femoral head and autologous bone grafting (42 interventions). Group B included 18 patients with 22 decompression operations along with introduction of a concentrate of autologous bone marrow and mesynchemal stem cells into the necrosis core. Four patients in group B had operations on both sides. A separae group $\mathrm{C}$ was six patients in whom a locking titanium implant for the femoral head was used which was developed at the clinic. Patients' stages of the disease according to the ARCO [16] are given in Table 1. Average age of patients was 40 years $(30 ; 47,5)$.

The study was conducted according to the recommendations of the institution scientific board and permission of the ethics board. Instructions on the application of the techniques developed were approved by the ministry of health of the Republic of Belarus in the established order.

Table 1

Stages of hip condition according to ARCO

\begin{tabular}{|c|c|c|}
\hline Stage & Number of cases & $\%$ \\
\hline I & 3 & 4.2 \\
\hline IIA & 2 & 3 \\
\hline IIB & 13 & 18.5 \\
\hline IIC & 23 & 33 \\
\hline IIIA & 29 & 41.3 \\
\hline Total & 70 & 100 \\
\hline
\end{tabular}

Group A patients underwent percutaneous core decompression with cannulated burrs followed by impaction bone plasty with autologous cancellous bone according to the patented method [17].

Under image intensifier, a Kirschner wire was introduced into the femoral neck in the direction to the necrotic core by $5 \mathrm{~mm}$ till the subchondral layer. Skin incision was $3 \mathrm{~mm}$. Along the guiding wire, a cylindrical bone graft was harvested with the burr from the intertrochanteric area of the femur. The affected anterosuperior zone of the femoral head was drilled with rounded burrs and tunneled with a curved awl inside the bone along the core centre circumference. Such type of osteoperforation, to our mind, provides decompression of the necrotic bone tissue in the core and does not impair the strength properties of the femoral head what may occur by circular drilling of dense necrotic bone. The arthroscope optics of $30^{\circ}$ was introduced for visual control of decompression quality and evaluation of bone vitality. Necrotic bone fragments were removed with a shaver under visual control. Arthroscopy was followed by joint sanation, chondroplasty and biopsy of the synovial membrane in seven cases with hip synovitis, free osseocartilaginous bodies, and signs of impingement syndrome.

Prior to decompression in group B, 60 to $80 \mathrm{ml}$ of bone marrow were harvested from the illiac wing in 10 cases. The material was centrifuged and a fraction of mononuclear cells (MNC) was separated. The MNC concentrate was mixed with autologous bone and then introduced intraosseously into the necrosis core. The outer part of the canal was closed with an autologous bone plug.

Autografting with mesenchymal stem cells (MSC) was used in 12 cases of group B. Cell therapy was used in the patients in the age of 25 to 45 years who did not have any bacterial or infection triggers but had an established vascular etiology of osteonecrosis. The technique included the following steps.

Bone marrow exfusion was performed with the technique described above. Bone marrow material in the volume of 50 to $70 \mathrm{ml}$ was transported in sterile conditions to the laboratory of the pediatric oncology and immunology centre for cell culturing. The patient was discharged for four weeks.

Biomedical cell product (BMCP) Extraction of MSCs was performed with their adhesion to plastic material from the bone marrow MNCs fraction and their culturing at the laboratory of cell biotechnology and citotherapy. Authentication of the cells was evaluated with immunophenotypic markers, their vitality was assessed, as well as sterility of BMCP MSC (Ya. I. Isaikina, head of laboratory). The cell product was studied with the method of histological staining. The cells in the culture were sealed in paraffin blocks; thin sections were produced which were stained with hematoxilin and eosin.

The fibrin gel was used as cell carrier [18]. The creation of the composite of BMCP MSC in the fibrin gel for filling the nectoric femoral head area included acquisition of the fibrin gel, injection of the cell MSC product into the fibrin gel, transfer of the composite into differentiational medium, cell culturing in $\mathrm{CO}_{2}-$ incubator for 4 to 5 days. The BMCP MSC prepared was used within two hours after its preparation (Fig. 1).

The patient was re-admitted to the hospital for a cell implantation procedure. The BMCP MSC material was transported from the laboratory of cell biotechnology on the day of the operation.

The surgical intervention had two phases and comprised necrotic core decompression and implantation of BMCP MSCs. Decompression was performed according to the techniques described 
above. MSC biograft was extracted from the culture medium during the intervention and was introduced into the necrotic core with the aid of a plunger pusher. The outer part of the bone canal was plugged with autologous bone to prevent cell product loss.

A locking titanium implant for the femoral head aimed to be used in FHN patients was developed at the institute for traumatology and orthopaedic jointly with Medbiotech. The device consists from a pistonshaped mesh cylinder made of bioinert material. It has a smooth plug and a cone screw for locking the cylinder in the femoral neck canal. The plug shape is convex and faces in direction to the articular surface for prevention of subchondral bone damage (Fig. 2). The implant was used in FHN stage IIIA to prevent rapid disease progression and preservation of hip joint function.

Technique of the intervention Necrotic core decompression was performed first. The tutanium implant which had been filled in with illiac wing autologous graft was hammered into the femoral head till its tough lock for correction of the collapsed area. In order to prevent backward migration, locking in the femoral neck canal was aided with a cone screw which diameter was $4 \mathrm{~mm}$ greater than the diameter of the meshe cylinder. Its cone shape provided its blocking in the centre of the cylinder, compressing the bone inside it. Application for a RB patent was filed.

Walking with crutches and partial loading of $10 \%$ of the body weight on the affected limb for 6 to 8 weeks was recommended in the postoperative period. Full weight-bearing was allowed after 8 to 12 weeks, depending on the type of intervention. Radiogrphic checks followed at 8 weeks, then 3, 6, and 12 months after the operation.

Pain was assessed with the visual analogue scale (VAS) [19]. Clinical evaluation included Harris Hip Score [20].

Statistical analysis was performed with nonparametric methods of data acquisition (median, quartiles, range) and comparison of general parameters of independent groups (Mann-Witney U-test). Results of long-term follow-up were processed with the Kaplan-Meier method. Statistica 10 package was used. Differences were considered significant at $\mathrm{p}<0.05$. Level of evidence -3 .
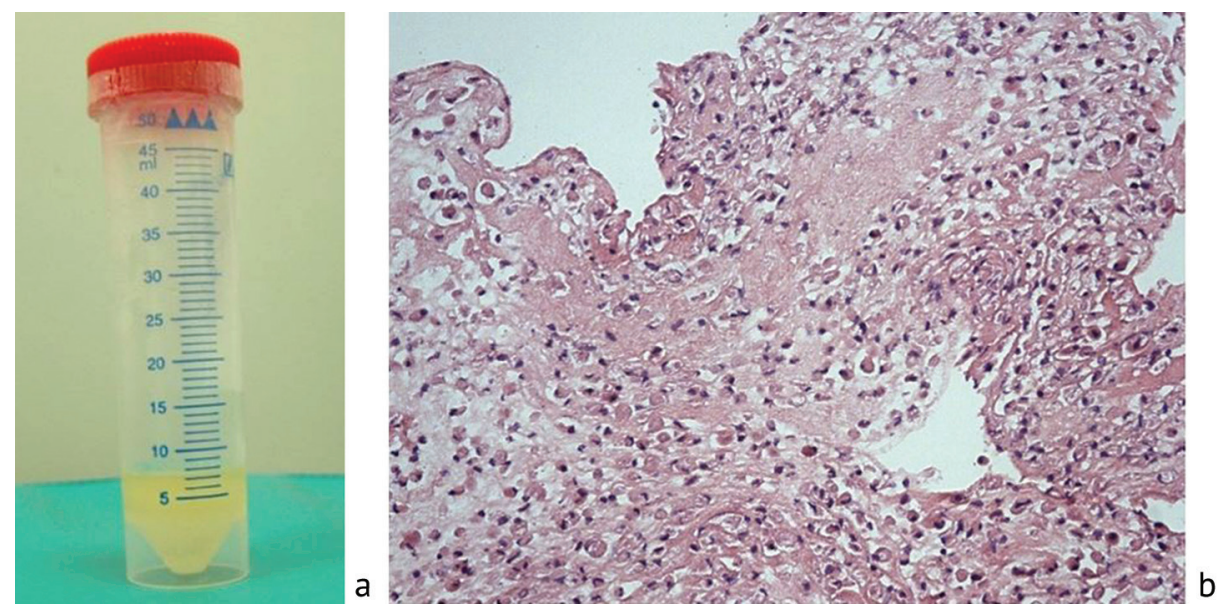

Fig. 1 Patient's D. BMCP MSC: $\boldsymbol{a}$ a tube with the cell product; $\boldsymbol{b}$ histological section of the composite; mag. $\times$ 600: a large number of monomorphic cells, small-sized and with a eosin rounded citoplasm and eccentric hyperchrome nucleus are seen in the vision filed; the cells are distributed evenly inside the carrier
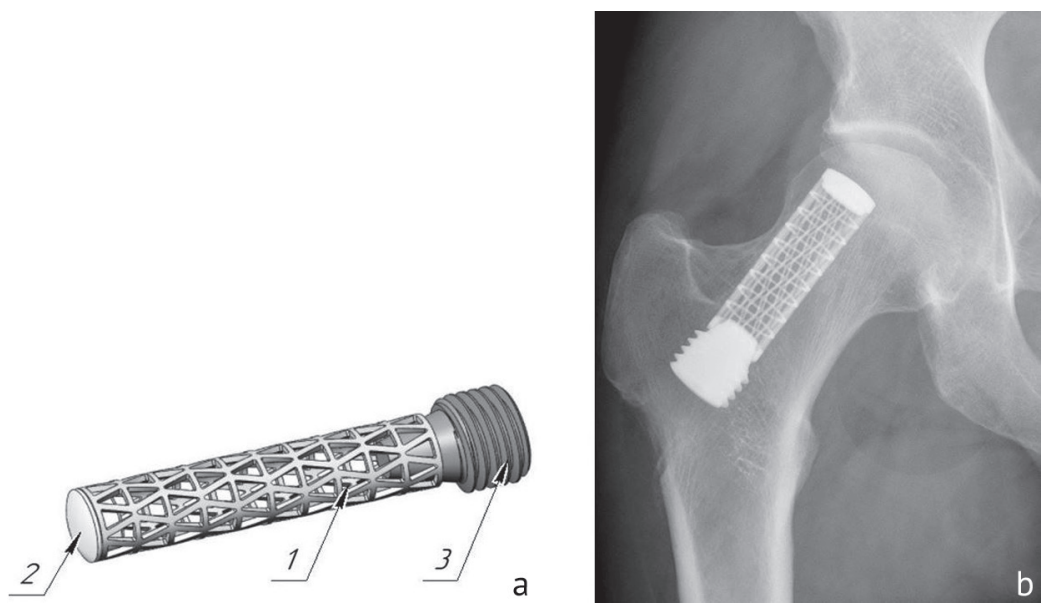

Fig. $2 \boldsymbol{a}$ Locking titanium implant for FHN management: 1 - titanium cylinder; 2 - plug; 3 - screw; $\boldsymbol{b}$ proximal femur X-ray of patient B., 45 years old, after treatment with the use of the titanium implant 


\section{RESULTS}

Results of hip-preserving interventions were studied in all the patients with follow-up of up to five years. Average follow-up was 20 months (range, 12-39.5 months). Differences were in the duration of inpatient stay, $10(8 ; 14)$ in group A and $8(6 ; 10)$ in group B $(p=0.013)$. Patients of group B were admitted a day prior to the interventions due to the necessity of BMCP MSC implantation immediately after its production and differentiation. Reduction in the postoperative period duration was realized by effective measures to arrest pain and low trama to tissues. Pain reduced from $60 \pm 4.2$ to $32 \pm 3.4$ VAS points in $42(60 \%)$ cases that, as we opine, was related to the decrease in the intraosseous pressure in the necrotic core due to decompression and joint unloading. Thirty-eight patients $(54.3 \%)$ noted pain relief or changes in the intensity of pain on the following day after the operation. Pain continued to decrease for three months and then no changes were noted $(p>0.05)$. Average preoperative HHS was 76 (70.8; 81.2), and at long-term follow-up it was $85.2(82 ; 88.4)$. Statistical analysis did not reveal any difference in the pain level between the groups $A$, B, C ( $p>0.05)$. It was established that hip-preserving operations which included implatation of MNCs and BMCP MSCs for osteoregeneration stimulation had a noticibly better results that when only bone plasty was used $(p<0.5)$. The THA rate was lower after hippreserving surgeries for FHN stages I-II than in stage III ( $\mathrm{p}<0.15)$ (Fig. 3).

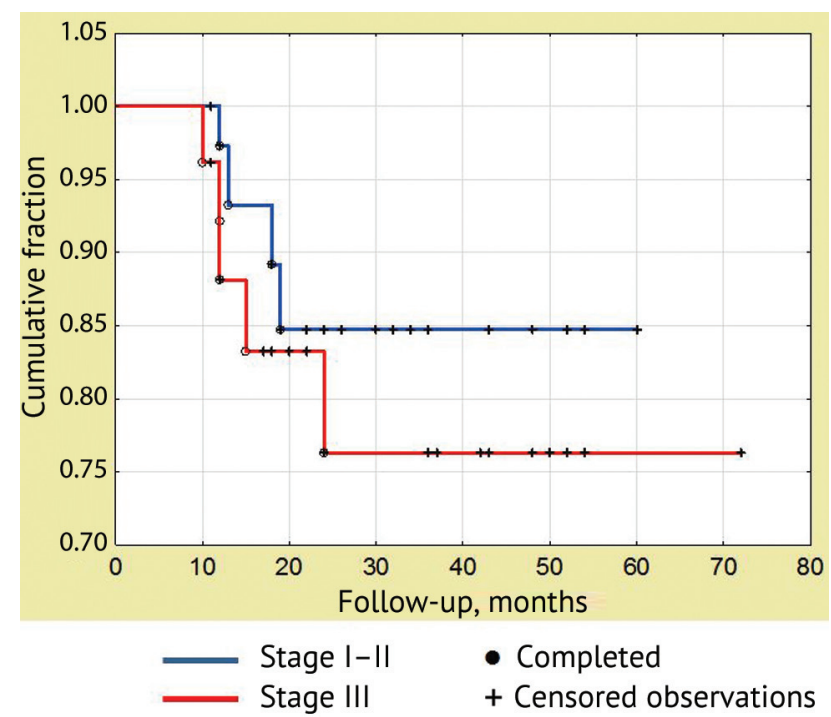

Fig. 3 Comparative analysis of success using the KaplanMeier method for different osteonecrosis stages

Total hip arthroplasty (THA) was performed in $10(14.3 \%)$ cases two years after hip-preserving operations. Differences between the groups in regard to the postoperative term were not significant
( $\mathrm{p}=0.38$, Mann-Witney U-test). Mean HHS was 63 points in those cases before the arthroplasty surgery $[60 ; 67]$. There was a radiographic progression of head collapse and increase in pain intensity. Hippreserving operations in those cases were performed for FHN stages IIC and IIIA but osteonecrosis was diagnosed very late so the management started also late. There was one total arthroplasty in group B. Postoperative changes in the femoral neck or head did not have any influence on the choice of the femoral stem, surgical approach and THA course.

The study of the results established that there were more poorer results in group A than in group B with bone marrow concentrate $(38.7 \%$ and $26.7 \%$, respectively). In group B, the number of cases with negative dynamics in osteonecrosis progression was lower by $12 \%$ than by bone plasty only. It proves that cell technologies are preferable in the FHN management in young patients. Our results correspond to the data published by other researchers, with the works of Hernigou [21], Zhao [22], Pak [23], in particular.

Long-term radiographs of seven patients $(10 \%)$ revealed "peak-shaped" hypertrophy of the lateral cortical layer of the femur in the site of cell product introduction. It was peculiar for MNC and BMCP MSC cases. Bone tissue outgrowth was not accompanied by clinical signs and, as assumed by us, was a sign of active bone formation in the zone of cell introduction. There was no bone hypertrophy in the bone plasty group.

The results in group $\mathrm{C}$ were studied after three to 12 months due to the novelty of the technique. Mean preoperative HHS was 76 [72; 80], and $88[86 ; 91]$ points in the postoperative period. Ability to work resumed after 3 months. None of the patients was conferred any disability group after the intervention. Disease progression was observed in one patient but THA was performed in none.

Case report A 28-year old patient applied to the institution hospital on 11.02.2015 and complained of intensive pain in the right hip joint and limping. Pain started six months prior. He was thoroughly examined according to the established protocol [24], and avascular femoral head necrosis in stage IIC was established. Bacterial and viral etiology was excluded. Laboratory tests did not detected bacteria in the urogenital tract, neither antibodies to viruses or bacteria in blood serum. Low invasive core decompression was performed 
and bone marrow MSCs were introduced. On the following postoperative day, excercise therapy and physiotherapy were initiated. Duration of unloading was eight weeks. The patient was able to work after 2.5 months. At a 5-year follow-up, the patient had no complains and walked without limping. Hip flexion on the right side was $120^{\circ}$, internal rotation $25^{\circ}$, external rotation $40^{\circ}$, and abduction $30^{\circ}$. Functional HHS outcome was 96 points. Leg axes were straight and there was no discrepancy in limb length (Fig. 4).
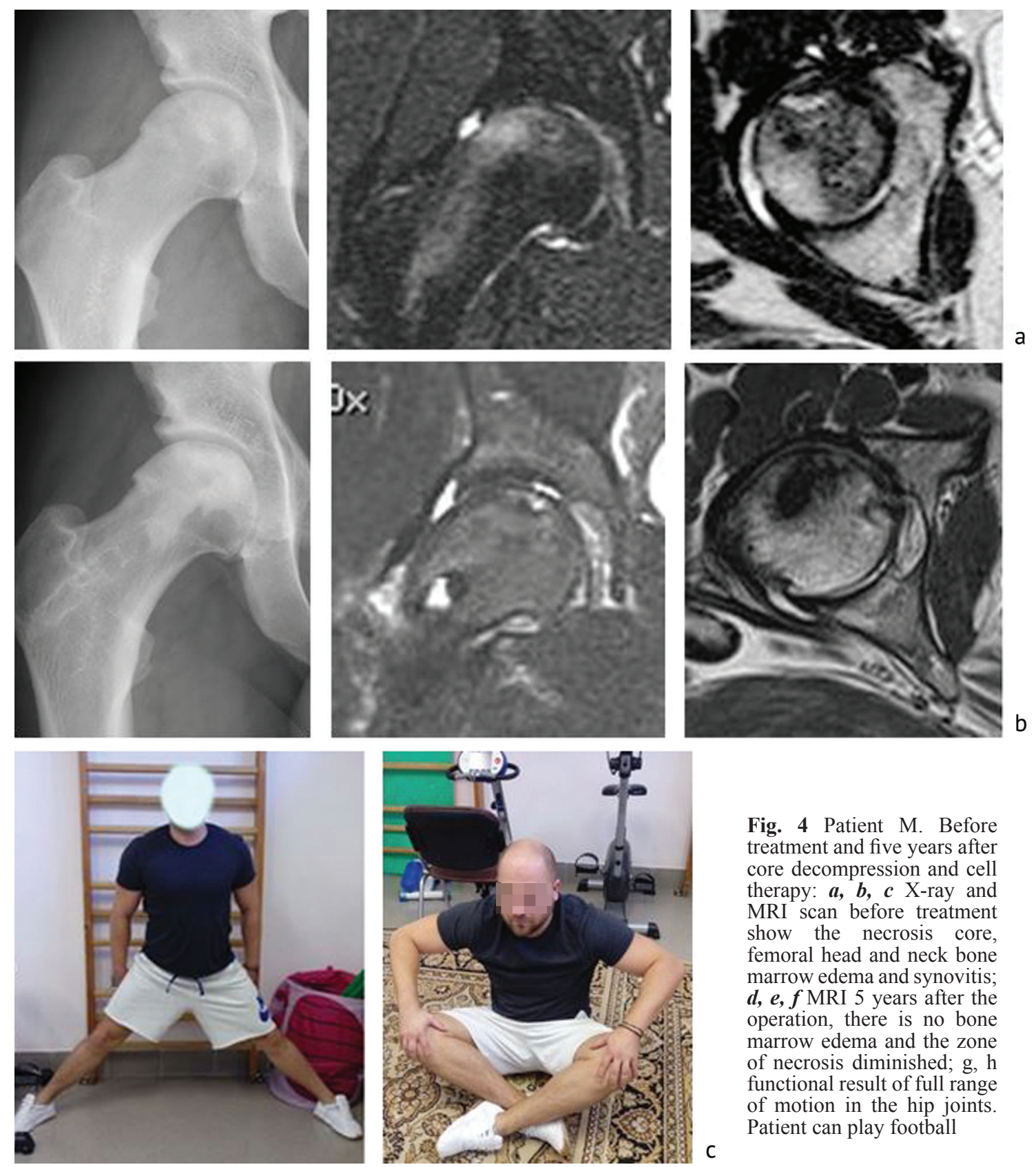

Fig. 4 Patient M. Before treatment and five years after core decompression and cell therapy: $\boldsymbol{a}, \boldsymbol{b}, \boldsymbol{c}$ X-ray and MRI scan before treatment show the necrosis core, femoral head and neck bone marrow edema and synovitis; $\boldsymbol{d}, \boldsymbol{e}, \boldsymbol{f}$ MRI 5 years after the operation, there is no bone marrow edema and the zone of necrosis diminished; $\mathrm{g}, \mathrm{h}$ functional result of full range of motion in the hip joints. Patient can play football

DISCUSSION

The efficiency of applying the differenciated MSCs for the FHN treatment has been associated with the disease pathology. There are data on the reduction in the progenitor cells that have the potential of bone restoration in the intact part of the femoral head adjacent to the necrosis area [25]. It results in the decrease in the agiogenesis rate, intramedullary vascularization and osteoblasts formation thus promoting osteonecrosis.

The development of cell technologies has been based on the experience of other researchers that used stem cells for regeneration in the femoral head [14, 18, $21,22]$. We have conducted an original experimental research on animals that proved that mature bone tissue of the compact structure with osteoblasts was formed in the site of mesenchymal cells introduction [26]. We adopted the technique developed to be used in humans.

The theoretical base for the efficiency of the low invasive interventions developed is the fact that surgical decompression decreases the intraosseous pressure and prevents progression of the necrotic 
processes in the femoral head. It was proven that MSCs when implanted in the femoral head necrotic region, differentiate into various cell lines that stimulate bone formation [27, 28]. The BMCP MSC, in its turn, stimulated the growth of granulation tissue that is the base for bone regeneration in the damaged zone. Our clinical material of the group with MSC implantation shows not only the improvement in the patients' condition but also a positive dynamics in the necrotic core what was studied by MRI (Fig. 4). Thus, the analysis of treatment results confirms the fact that application of BMCP MSC adds to the therapeutic effect of surgical decompression of the necrosis core and improves the clinical condition of patients.

Various methods of introducing the cell product into the femoral head have been described. Intraarterial delivery of autogenous MSCs via the medial circumflex femoral artery was used [29], which seems doubtfull as there could not be any direct targeted effect on the femoral head. It was calculated that the average purposeful number of MSCs for implantation into the femoral head changed by necrosis should be 35,000 [30]. The technique proposed by Tabatabaee et al. might be considered for this purpose as the authors used a liquid cell product for intoduction into the head which was injected with a long syringe through the drilled canal of 2.7-mm diameter [31]. However, such a technique will enevitably result in the loss of cell product by the reverse blood flow due to intraosseous cancellous bone bleeding after femoral neck drilling. This reverse effect was observed by us when we used MNCs. To preserve the cells delivered, to our mind, is possible with a carrier that is able to retain the cells in the implantation site. It was presented in our work. The cell tecnology developed by us for FHN treatments provides retention of $95 \%$ of cells in the BMCP MSC, introduced in a low invasive way without large surgical cuts thanks to the surgical intervention patented [17].

The results of the histological study undertaken for the study of the femoral heads removed at THA show that stage III of the disease is characterized by flattening and deformity of the trabecular structures located under the subchondral plate of the femoral head that impair its strength [32]. The results of FHN treatment indicate that the disease continued to progress in stages IIIA and IIC that was maifested by appearence and increase in the collapse of the loading zone. Therefore, we propose to use a mesh titanium implant in combination with bone plasty as a hippreserving intervention in these stages. In the cases with the implant, the signs of necrosis progression were absent in the follow-up period. There was no need in THA performance.

\section{CONCLUSIONS}

The analysis of long-term results of these minimally invasive technologies developed and introduced into practice has proven their efficacy and safety along with a low rate of complications. It seems reasonable to use the variants of hip-preserving operations for femoral head necrosis stages I, IIA, IIB, IIC to postpone the time of possible hip joint arthroplasty. Cell technologies are preferable and promising in the treatment of osteonecrosis in young patients.

The techniques developed have pathogenetic substatiation as their impact is exclusively directed to the lesion core. They enable to avoid negative consequences related to the performance of the osteotomy of the femur and do not hinder the performance of joint replacement if there is a need in the future.

The restoration of the loading zone in stage IIIA requires bone palsty surgery along with structured grafts or locking implants that are capable to fulfill the bearing function. The locking mesh titanium implant satisfies these conditions and its available sizes provide a personalized treatment approach.

\section{REFERENCES}

1. Murzich A.E., Eismont O.L., Isaikina Ia.I., Bukach D.V., Sirotkin R.S. Kletochnye tekhnologii v lechenii nekroza golovki bedrennoi kosti [Cell technologies in the treatment of the femoral head necrosis]. Izvestiia Natsionalnoi Akademii Nauk Belarusi. Seriia Meditsinskikh Nauk, 2018, vol. 15, no. 4, pp. 429-441. (in Russian) DOI: 10.29235/1814-6023-2018-15-4-429-441

2. Kamal D., Traistaru R., Alexandru D.O., Grecu D.C., Mogoantă L. Epidemiologic study of avascular necrosis of the femoral head. Curr. Health Sci. J., 2013, vol. 39, no. 3, pp. 169-174.

3. Malizos K.N., Karantanas A.H., Varitimidis S.E., Dailiana Z.H., Bargiotas K., Maris T. Osteonecrosis of the femoral head: etiology, imaging and treatment. Eur. J. Radiol., 2007, vol. 63, no. 1, pp. 16-28. DOI: 10.1016/j.ejrad.2007.03.019

4. Tikhilov R.M., Shubniakov I.I., Kovalenko A.N., Chernyi A.Zh., Muraveva Iu.V., Goncharov M.Iu. Dannye registra endoprotezirovaniia tazobedrennogo sustava RNIITO im. R.R. Vredena za 2007-2012 gody [Data from the register of the hip arthroplasty of Russian Vreden Scientific Research Institute of Traumatology and Orthopaedics for 2007-2012]. Travmatologiia i Ortopediia Rossii, 2013, no. 3 (69), pp. 167-190. (in Russian)

5. Hernigou P., Beaujean F. Treatment of osteonecrosis with autologous bone marrow grafting. Clin. Orthop. Relat. Res., 2002 , no. 405, pp. 14-23. DOI: 10.1097/00003086-200212000-00003

6. Tikhilov R.M., Shubniakov I.I., Miasoedov A.A., Irzhanskii A.A. Sravnitelnaia kharakteristika rezultatov lecheniia rannikh stadii osteonekroza golovki bedrennoi kosti razlichnymi metodami dekompressii [A comparative characteristic of the results of treating early stages of the femoral head osteonecrosis with various decompression techniques]. Travmatologiia i Ortopediia Rossii, 2016, vol. 22, no. 3, pp. 7-21. (in Russian) DOI: $10.21823 / 2311-2905-2016-22-3-7-21$ 
7. Mont M.A., Ragland P.S., Etienne G. Core decompression of the femoral head for osteonecrosis using percutaneous multiple small-diameter drilling. Clin. Orthop. Relat. Res., 2004, no. 429, pp. 131-138. DOI: 10.1097/01.blo.0000150128.57777.8e

8. Song W.S., Yoo J.J., Kim Y.M., Kim H.J. Results of multiple drilling compared with those of conventional methods of core decompression. Clin. Orthop. Relat. Res., 2007, vol. 454, pp. 139-146. DOI: 10.1097/01.blo.0000229342.96103.73

9. Konev V.A., Tikhilov R.M., Shubniakov I.I., Miasoedov A.A., Denisov A.O. Effektivnost ispolzovaniia biorezorbiruemykh materialov dlia zapolneniia kostnykh polostei pri osteonekroze golovki bedrennoi kosti [The effectiveness of using bioresorbable materials to fill bone cavities for the femoral head osteonecrosis]. Travmatologiia i Ortopediia Rossii, 2014, no. 3 (73), pp. 28-38. (in Russian)

10. Buckley P.D., Gearen P.F., Petty R.W. Structural bone-grafting for early atraumatic avascular necrosis of the femoral head. J. Bone Joint Surg. Am., 1991, vol. 73, no. 9, pp. 1357-1364.

11. Landgraeber S., Theysohn J.M., Classen T., Jäger M., Warwas S., Hohn H.P., Kowalczyk W. Advanced core decompression, a new treatment option of avascular necrosis of the femoral head - a first follow-up. J. Tissue Eng. Regen. Med., 2013, vol. 7, no. 11, pp. 893-900. DOI: 10.1002/term.1481

12. Kim S.Y., Kim Y.G., Kim P.T., Ihn J.C., Cho B.C., Koo K.H. Vascularized compared with nonvascularized fibular grafts for large osteonecrotic lesions of the femoral head. J. Bone Joint Surg. Am., 2005, vol. 87, no. 9, pp. 2012-2018. DOI: 10.2106/JBJS.D.02593

13. Kotelnikov G.P., Lartsev Iu.V., Kudashev D.S., Zuev-Ratnikov S.D., Shorin I.S. Sposob kombinirovannoi impaktsionnoi autoplastiki golovki bedrennoi kosti [The way of combined impaction autoplasty of the femoral head]. Patent RF no. 2583577, A61B 17/56, 2014. (in Russian)

14. Gorbatenko A.I. Uspeshnyi opyt ispolzovaniia obogashchennoi trombotsitami autoplazmy v lechenii asepticheskogo nekroza golovki bedrennoi kosti [Successful experience of using platelet-rich autoplasma in the treatment of aseptic femoral head necrosis]. Sb. tez. VII Vseros. Simp. s mezhdunar. uchastiem "Aktualnye Voprosy Tkanevoi i Kletochnoi Transplantologii" [Proceedings of the VII all-Russian Symposium with international participation "Actual Problems of Tissue and Cell Transplantology"]. Astrakhan, 2017, pp. 193-196. (in Russian)

15. Korytkin A.A., Zakharova D.V., Tenilin N.A., Zykin A.A., Gerasimov S.A., Novikova Ia.S. Sposob khirurgicheskogo lecheniia avaskuliarnogo nekroza golovki bedrennoi kosti [The way of surgical treating avascular femoral head necrosis]. Patent RF no. 2652584, A61B 17/00 A61B 17/56, 2017. (in Russian)

16. ARCO (Association Research Circulation Osseous). Committee on terminology and classification. ARCO News, 1992, no. 4, pp. 41-46.

17. Beletskii A.V., Murzich A.E. Sposob khirurgicheskogo lecheniia avaskuliarnogo nekroza golovki bedra u vzroslogo [The way of surgical treating avascular femoral head necrosis in an adult person]. Patent of the Republic of Belarus no. 22648, A 61B 17/56, 2018. (in Russian)

18. Zhernosechenko A., Isaikina Ia., Mikhalevskaia T. Vybor nositelia i uslovii differentsirovki mezenkhimalnykh stvolovykh kletok dlia vosstanovleniia kostnoi tkani [Selection of a carrier and conditions for differentiation of mesenchymal stem cells for the restoration of bone tissue]. Nauka $i$ Innovatsii, 2019, no. 5 (195), pp. 58-61. (in Russian)

19. McCormack H.M., Horne D.J., Sheather S. Clinical applications of visual analogue scales: a critical review. Psychol. Med., 1988, vol. 18, no. 4, pp. 1007-1019. DOI: 10.1017/s0033291700009934

20. Harris W.H. Traumatic arthritis of the hip after dislocation and acetabular fractures: treatment by mold arthroplasty. An end-result study using a new method of result evaluation. J. Bone Joint Surg. Am., 1969, vol. 51, no. 4, pp. 737-755.

21. Hernigou P., Poignard A., Zilber S., Rouard H. Cell therapy of hip osteonecrosis with autologous bone marrow grafting. Indian J. Orthop., 2009, vol. 43 , no. 1, pp. 40-45. DOI: 10.4103/0019-5413.45322

22. Zhao D., Cui D., Wang B., Tian F., Guo L., Yang L., Liu B., Yu X. Treatment of early stage osteonecrosis of the femoral head with autologous implantation of bone marrow-derived and cultured mesenchymal stem cells. Bone, 2012, vol. 50, no. 1, pp. 325-330. DOI: 10.1016/j.bone.2011.11.002

23. Pak J. Autologous adipose tissue-derived stem cells induce persistent bone-like tissue in osteonecrotic femoral heads: a molecular mechanism. Pain Physician, 2012, vol. 15, no. 1, pp. 75-85.

24. Murzich A.E., Beletskii A.V., Poleshchuk N.N. Osteonekroz golovki bedra: osobennosti terminologii i diagnosticheskii algoritm v sovremennykh usloviiakh [Osteonecrosis of the femoral head: characteristic features of terminology and diagnostic algorithm in modern conditions]. Khirurgiia. Vostochnaia Evropa, 2018, vol. 7, no. 2, pp. 179-188.

25. Hernigou P., Beaujean F., Lambotte J.C. Decrease in the mesenchymal stem-cell pool in the proximal femur in corticosteroid-induced osteonecrosis. J. Bone Joint Surg. Br., 1999, vol. 81, no. 2, pp. 349-355. DOI: 10.1302/0301-620x.81b2.8818

26. Murzich A.E., Pashkevich L.A., Zhernosechenko A.A. Eksperimentalnoe obosnovanie sposoba autotransplantatsii mezenkhimalnykh stvolovykh kletok dlia regeneratsii kostnoi tkani golovki bedra [Experimental substantiation of the method of autotransplantation of mesenchymal stem cells for regeneration of femoral head bone tissue]. Izvestiia Natsionalnoi Akademii Nauk Belarusi. Seriia Meditsinskikh Nauk, 2020, vol. 17, no. 1, pp. 7-19. DOI: $10.29235 / 1814-6023-2020-17-1-7-19$

27. Xiao Z.M., Jiang H., Zhan X.L., Wu Z.G., Zhang X.L. Treatment of osteonecrosis of femoral head with BMSCs-seeded bio-derived bone materials combined with rhBMP-2 in rabbits. Chin. J. Traumatol., 2008, vol. 11, no. 3, pp.165-170. DOI: 10.1016/s1008-1275(08)60035-8

28. Tzaribachev N., Vaegler M., Schaefer J., Reize P., Rudert M., Handgretinger R., Müller I. Mesenchymal stromal cells: a novel treatment option for steroid-induced avascular osteonecrosis. Isr. Med. Assoc. J., 2008, vol.10, no. 3, pp. 232-234.

29. Mao Q., Jin H., Liao F., Xiao L., Chen D., Tong P. The efficacy of targeted intraarterial delivery of concentrated autologous bone marrow containing mononuclear cells in the treatment of osteonecrosis of the femoral head: a five year follow-up study. Bone, 2013, vol. 57, no. 2, pp. 509-516. DOI: $10.1016 /$ j.bone.2013.08.022

30. Homma Y., Kaneko K., Hernigou P. Supercharging allografts with mesenchymal stem cells in the operating room during hip revision. Int. Orthop., 2014 , vol. 38 , no. 10 , pp. 2033-2044. DOI: $10.1007 / \mathrm{s} 00264-013-2221-\mathrm{x}$

31. Tabatabaee R.M., Saberi S., Parvizi J., Mortazavi S.M., Farzan M. Combining concentrated autologous bone marrow stem cells injection with core decompression improves outcome for patients with early-stage osteonecrosis of the femoral head: a comparative study. J. Arthroplasty, 2015, vol. 30, no. 9 Suppl., pp. 11-15. DOI: 10.1016/j.arth.2015.06.022

32. Mokhammadi M.T., Pashkevich L.A., Eismont O.L., Murzich A.E. Patomorfologiia golovki bedrennoi kosti pri asepticheskom nekroze [Pathomorphology of the femoral head for aseptic necrosis]. Khirurgiia. Vost. Evropa, 2017. Prilozhenie: Materialy III Resp. Nauch.-prakt. Konf. s mezhdunar. uchastiem po artroskopii «Artroskopicheskaia i Maloinvazivnaia Khirurgiia Plechevogo Sustava» [Supplement: Materials of the III Republican Scientific-Practical Conference on Arthroscopy with international participation "Arthroscopic and Little Invasive Surgery of the Shoulder"]. Minsk, 2017, pp. 148-156. (in Russian)

Received: 10.04 .2020

\section{Information about the authors:}

1. Alexander E. Murzich, M.D., Ph.D.,

State Institution Republican Scientific-Practical Centre of Traumatology and Orthopedics, Minsk, Belarus, Email: mae77@list.ru

2. Oleg A. Sokolovsky, M.D., Ph.D., Professor,

State Institution Republican Scientific-Practical Centre of Traumatology and Orthopedics, Minsk, Belarus,

Email: sakalouski@yandex.ru

3. Gennady A. Uryev, M.D., Ph.D.,

State Institution Republican Scientific-Practical Centre of Traumatology and Orthopedics, Minsk, Belarus, Email: uryev11@tut.by 